\title{
Peer Attachment, Fathering, Social Media Use and Perception of Premarital Sexual Attitude among Teenagers
}

\author{
Yulina Eva Riany ${ }^{\left.1^{*}\right)}$, Belinda Handayani ${ }^{2}$ \\ ${ }^{1}$ Parenting and Family Support Centre, The University of Queensland, Brisbane, Australia. \\ ${ }^{1,2}$ Department of Family and Consumer Sciences, Faculty of Human Ecology, IPB University, \\ Bogor 16680, West Java, Indonesia \\ *) Corresponding author: yriany@apps.ipb.ac.id
}

\begin{abstract}
This study aimed to analyze the links among peer attachment, fathering, social media use, and the perception of premarital sexual among adolescents. Two hundred and four high school (SMA) students and 114 Vocational High School (SMK) students voluntarily participated in this online survey. Results showed fathering was negatively associated with the perception of premarital sex among adolescents in which participants with positive experiences in fathering would report low score in perception of premarital sexual. On the other hand, social media use was significantly linked to the high score of perception of premarital sexual. Regression analysis indicated participants' dating experience, lack of fathering experience and high social media use to be predictors for the perception of premarital sex among adolecscent.
\end{abstract}

Keywords: adolescents, fathering, peer attachment, perceptions of premarital sexual, social media use

\begin{abstract}
Abstrak
Penelitian ini bertujuan untuk menganalisis keterkaitan antara keterikatan teman sebaya, peran ayah, penggunaan media sosial dan persepsi tentang seks pranikah pada remaja. Survei online ini diikuti oleh dua ratus empat siswa Sekolah Menengah Atas (SMA) dan 114 siswa Sekolah Menengah Kejuruan (SMK). Hasil penelitian menunjukkan pola ayah berhubungan negatif dengan persepsi seks pranikah pada remaja dimana partisipan dengan pengalaman positif dalam menjadi ayah akan melaporkan skor rendah dalam persepsi seksual pranikah. Di sisi lain, penggunaan media sosial memiliki keterkaitan yang signifikan dengan tingginya skor persepsi seksual pranikah. Analisis regresi menunjukkan pengalaman berpacaran partisipan, kurangnya pengalaman menjadi ayah dan penggunaan media sosial yang tinggi menjadi pengaruh terhadap persepsi seks pranikah di kalangan remaja.
\end{abstract}

Kata kunci: kelekatan sebaya, penggunaan media sosial, peran ayah, persepsi seksual pranikah, remaja

\section{Introduction}

Adolescents experience a transitional period from childhood to adulthood with an age range between 10-24 years (Santrock, 2019). In the transitional period, adolescents have changes in biology, cognitive, and social emotions that lead to changes in their 
sexual development. These adolescents also expose many positive and negative behavior changes due to their identity seeking in this period.

Kusumaryani and Antarwati (2017) indicated that adolescence have significant changes in their physical and sexual attractions and these changes lead them to changes in their perception of premarital sexual behaviours. According to Azinar (2013), sexual behavior in adolescents is the result of several factors originating internally and externally, including religiosity, knowledge, influence from friends, media information and parental interactions. Reiss (1964) indicated several stages of sexual behaviour among adolescents. These include stealing glances at sensual parts, holding hands, sitting side by side, hugging, kissing, touching sensitive parts, attaching genitals, rubbing genitals, oral sex and intercourse (intercourse) (Reiss, 1964; de Paul Kanwetuu, Mokulogo, \& Azumah, 2018).

Data from the Demographic and Reproductive Health Survey of Indonesian Adolescents (2017) indicated that approximately 21 percent of girls and 26 percent of boys get information about their peers' reproductive health. Adolescence forms social networks with friends and this is an important development and adolescents will try to follow the attitude of values towards their friends' behavior (McMillan, Felmlee, \& Osgood, 2018; Widyastuti, 2009). However, Najib's (2018) research results show that there are more peers who have bad effects than good ones in sexual behaviours among adolescents.

Besides, Suwarni, Ismail, Prabandari, and Adiyanti (2015) found that parental monitoring related to sexual behavior was another important factor to control the attitude toward premarital sexual behaviours among adolescents. Parental monitoring influences attitudes about adolescent sexual behaviour (Inguglia, Costa, Ingoglia, Cuzzocrea, \& Liga, 2020; Rostiawan, Yusuf, \& Dahlan, 2020; Tomić, Burić, \& Štulhofer, 2018). However, in Indonesia, providing information about premarital sex is still considered taboo because parents are worried that when providing information about sex means parents teach their children to have sexual relations.

Among Indonesian families, parenting is mostly focused on the role of the mother though father and mother have complement function in parenting. In relation to sex education, the role of the father should also be involved in parenting (Mpondo, Ruiter, Schaafsma, Van Den Borne, \& Reddy, 2018; Zakiyah, Prabandari, \& Triratnawati, 2016). Nasution and Septiani's research (2017) found that the absence of a father figure in physical and emotional care will impact children's negative behavior, such as being rude to their friends and not easily adapting to rules and norms in the environment.

In addition to the lack of father control in sex education among adolescents, adolescents' great curiosity even makes them doing exploration (Santrock, 2019). Many teenagers are looking for information about sexual behavior through social media information which is in demand and favor because of its easy access (Solikah, Herlina, \& Masnina, 2015). Multiple factors, such as exposure to the sexual information from media, peer pressure to try new things and the lack of control from parents often lead teenagers to fall into the world of free sex through social media (Solikah et al., 2015). Data reported by IDN TIMES (2018) in June found that the Ministry of Health (Kemenkes) conducted a screening for pornography addiction among junior and high schools students. A total of 1,314 respondents in the South Jakarta and Pandeglang districts who participated in the study reported that most of them were exposed to pornography and that was only 1.7 percent of students were not exposed to pornography. 
Accordingly, this study aimed to (1) analyse adolescent characteristics, father characteristics, peer attachment, fathering, media social use and perception of premarital sex in adolescents, (2) analyse the relationship between peer influence, fathering, social media use and perception of premarital sex in adolescents, (3) analyse the influence of peers, fathering, media social use on perception of premarital sex among adolescents.

\section{Methods}

\section{Participants}

This research employed a volunteer sampling technique, in which respondents choose for themselves to participate in this study through the media with the criteria of adolescents high school or vocational school and still have a father. The number of respondents involved 320 people spread across 29 provinces in Indonesia. This study's primary data included adolescent characteristics, father characteristics, peer attachment, fathering, social media use, and premarital sex.

\section{Measurement}

This study employed numbers of questionnaires that have been translated into Bahasa Indonesia. The questionnaires were translated and back-translated using Brislin's translation technique (Brislin, 1970). Translations were initially conducted independently by the author and another author who was unconnected to this research project. Both, an online questionnaire trial was conducted to check validity and reliability of the questionnaires.

Inventory of Parent And Peer Attachment (IPPA) (Armsden, \& Greenberg, 1987) is instrument consists of 25 questions and has 3 dimensions, including trust, communication, and isolation. The peer attachment instrument consisted of 10 questions of trust, 8 questions of communication, and 7 questions of isolation and this questionnaire use Likert-scale (from $1=$ never to $5=$ always). Cronbach's scores for negligence for this instrument were 0.893 for trust, 0.716 for communication, and 0.646 for isolation, and 0.727 for total peer attachment. Peer attachment is categorized into three categories according to the performance of the index, namely low (0-60), moderate (60-80), and high (80-100).

Fatherhood Scale (FS) [Bahasa Indonesia version] (Dick, 2004). Fathering was measured by Fatherhood Scale. The instrument consists of nine dimensions of fathering: positive involvement, positive emotional response, negative involvement, father's moral role, father's gender role, a good provider, androgynous role, responsibility, and father acceptance. This instrument's number of questions is 63 questions using 5 scale of Likert Scale (from $1=$ never to $5=$ always). Cronbach's alpha value of this instrument is 0.945 . Each item is assigned a value of 1 to 5 and for the 11 statements on the negative engagement dimension, inverse. The category on the fatherhood scale instrument, with a total score below 128, is that fathers are rarely involved in positive parenting and above 256 , namely that the perception of the involvement of fathering is positive for the child.

Social Networking Usage Questionnaire: Development and Validation in an Indian Higher Education Context (SNUQ) (Gupta, \& Bashir, 2018). The social media use in this study was measured using the SNUQ and this instrument consists of 19 questions and has four dimensions, namely academic, socialization, entertainment, and information. After data collection and reliability testing are carried out, there is one dimension: 
unreliable entertainment so that the questionnaire on social media use becomes 3 dimensions: academic, socialization, and information. for a total of 15 questions using 5 scale of Likert Scale (from $1=$ never to $5=$ always). The Cronbach's alpha score for this instrument is 0.740 for academics, 0.530 for socialization, 0.502 for information, and 0.764 for social media use. The use of social media is categorized into three categories according to the performance of the index: low (0-60), moderate (60-80), and high (80100).

Premarital Sex (PS) (Reiss, 1964). The measurement of perception about premarital sexual behaviour among adolescents used a Premarital Sex questionnaire. This questionnaire refers to the theory of premarital attitude dimensions by and the sexual diagram stages by Rahardjo et al. (2017). Reiss theory (1964) divides the existence of two groups of individuals in sexual behavior actors (1) Permisiveness with affection which states that premarital sex behavior is justified on the basis of love and (2) Permiseveness without affection which explains that sex behavior can be done even without love and there are 4 dimensions: Love, Affection, Petting, and Without affection. Besides using the sexual diagram by Rahardjo et al. (2017), there is a sequence of sexual behavior such as holding hands, hugging, and making out to sexual intercourse. This questionnaire is only limited to measuring adolescent attitudes regarding premarital sex. The processing of this questionnaire uses factor analysis in SPSS 25.0 and there are 16 questions with two factors that can explain the pre-marital sexual variable with a minimum value of 0.4 . Cornbach's alpha were 0.899 for non-risk behavior, 0.739 for risky behavior, and 0.882 for premarital sex. This instrument employed Likert scale $(1=$ strongly disagree and $5=$ strongly agree). Premarital sexuality is categorized into three categories according to the performance of the index, good (0-60), moderate good (60$80)$, and not good (80-100).

\section{Analysis}

Primary data from 320 respondents were analysed descriptively and statistically inferential using Statistical Package for Social Science (SPSS) 25.0. The statistical analysis used is descriptive analysis to see the frequency, means, maximum value, minimum value, and standard deviation. Inference statistics for the spearman correlation test to test the relationship between variables, and regression analysis to test the effect of independent and dependent variables.

\section{Findings}

The characteristics of adolescents include participants' age, gender, type of education, regional origin, and dating experience. Father characteristics consist of fathers' age, education, income, occupation, and family size. The results showed that most of the respondents $(76.3 \%)$ were male and $23.8 \%$ were female. Approximately 64.4 percent of adolescents enrolled in high schools (SMA) and 35.6 percent vocational high schools (SMK). Most $(80.0 \%)$ of adolescents come from Java. Meanwhile, more than half of adolescents $(55.7 \%)$ had dating experience and 44.3 percent had no dating experience. Detail information related to participants' demographic characteristics is presented on Table 1. 
Table 1. Respondents Demographic Characteristics

\begin{tabular}{|c|c|c|}
\hline Characteristic & $\mathbf{N}=\mathbf{3 2 0}$ & $\%$ \\
\hline \multicolumn{3}{|l|}{ Adolescents characteristics } \\
\hline \multicolumn{3}{|l|}{ Gender } \\
\hline Male & 76 & 23.8 \\
\hline Female & 244 & 76.3 \\
\hline \multicolumn{3}{|l|}{ Age } \\
\hline 15 years old & 23 & 7.2 \\
\hline 16 years old & 87 & 27.2 \\
\hline 17 years old & 138 & 43.1 \\
\hline 18 years old & 70 & 21.9 \\
\hline 19 years old & 2 & 0.6 \\
\hline \multicolumn{3}{|l|}{ Type of Education } \\
\hline Senior High School (SMA) & 206 & 64.4 \\
\hline Vocational High School (SMK) & 114 & 35.6 \\
\hline \multicolumn{3}{|l|}{ Origin } \\
\hline Java & 256 & 80.0 \\
\hline Sumatera & 40 & 12.5 \\
\hline Kalimantan & 14 & 4.4 \\
\hline Sulawesi & 3 & 0.9 \\
\hline Maluku and Papua & 2 & 0.6 \\
\hline Bali and Nusa Tenggara & 5 & 1.6 \\
\hline \multicolumn{3}{|l|}{ Dating Experience } \\
\hline Have ever & 166 & 51.9 \\
\hline Have never & 152 & 48.1 \\
\hline \multicolumn{3}{|l|}{ Fathers charactersitics } \\
\hline \multicolumn{3}{|l|}{ Age chategorizes } \\
\hline Early adulthood (20-40 years old) & 19 & 6.0 \\
\hline Middle Adulthood ( $40-65$ years old) & 298 & 93.1 \\
\hline \multirow{2}{*}{\multicolumn{3}{|c|}{ Occupation }} \\
\hline & & \\
\hline Unemployed & 9 & 2.8 \\
\hline Farmer/ Miner & 12 & 3.8 \\
\hline Laboure & 20 & 6.3 \\
\hline Private Employee & 90 & 28.1 \\
\hline Entrepreneur & 77 & 24.1 \\
\hline Civil Servant & 36 & 11.3 \\
\hline Retiree & 18 & 5.6 \\
\hline Etc & 58 & 18.1 \\
\hline \multicolumn{3}{|l|}{ Education } \\
\hline Not Complete Elementary School & 5 & 1.6 \\
\hline Elementary School & 17 & 5.3 \\
\hline Junior High School & 18 & 5.6 \\
\hline Senior High School & 119 & 37.2 \\
\hline Diploma & 34 & 10.6 \\
\hline Bachelor degree & 127 & 39.7 \\
\hline \multicolumn{3}{|l|}{ Income $^{a}$} \\
\hline$<$ IDR 1.000 .000 & 50 & 15.6 \\
\hline IDR1.000.000- Rp 3.000.000 & 88 & 27.5 \\
\hline IDR 3.000.000- Rp 5.000.000 & 82 & 25.6 \\
\hline > IDR 5.000 .000 & 100 & 31.3 \\
\hline \multicolumn{3}{|l|}{ Family size } \\
\hline Small Family (1-4 people) & 155 & 48.4 \\
\hline Moderate Family (5-7 people) & 159 & 49.7 \\
\hline Big Family $(>7$ people) & 6 & 1.9 \\
\hline
\end{tabular}

Note: ${ }^{\text {IIndonesia Rupiah }}$ 
Peer attachment has been categorized into three dimensions: Trust, Communication, and Isolation (Armsden \& Greenberg, 1987). A sense of security characterizes trust, trust, and confide in adolescents' hearts to their peers. Communication is characterized by sharing stories of problems and isolation, characterized by isolated, shunned adolescents from their peer environment. The results showed that most of the adolescents was categorized to have low level of secure attachment (71.6\%), medium level of secure attachment (22.8\%), and high level of secure attachment (5.6\%). In this study, the dimensions of trust and communication were in the low category, while for isolation it was in the low category where adolescents did not feel isolated.

Dick (2004) categorized fathering into nine dimensions: Positive involvement, Positive emotional response, Negative involvement, Moral roles, Gender roles, Good providers, Androgynous roles, Responsibility, and Father acceptance. In this study, fathering score was collected through participants' perceptions of their father's involvement in the parenting practices experienced. The fathering score was categorised into three levels: positive, moderate and negative categories. The positive fathering indicated that father's involvement in parenting practices is very positive while the negative fathering referred lack of positive parenting behavior in parenting practices experienced by the participants. The moderate fathering indicated that the father has been involved in positive parenting with the child quite often but it is not optimal. The results showed that the majority of adolescents perceived to experience moderate fathering with $85.3 \%$. Only $14.4 \%$ participants were perceived to have positive fathering, and only $0.3 \%$ of adolescents reported negative fathering.

Social media is an online media where users can easily expand interactions, participate, share various things (Putri, Nurwati, \& Budiarti, 2016). In this study, the social media has been categorized into three dimensions: Academic, Socialization, and Information (Gupta \& Bashir, 2018). Academic dimension refers to participants' use in social media to study and accomplish assignments and examinations. Socialization dimesions relate to social media use to hang out, communicate with family and friends, and build social networks. Information dimension is defined as the use of social media to get news/ information or anything associated with accomplishing assignments. The results showed that most of the adolescents were in the low category of social media use $(73.4 \%)$, medium category $(17.8 \%)$, and high category $(8.8 \%)$.

This study's perception of premarital sexuality refers to risk to have premarital behaviours. The results showed that almost all participants in this study were categorized to have low risk of premarital and risk behavior $(73.1 \%)$, moderate risk of premarital sexual behaviour (24.1\%), and high risk of premarital sexual behaviour $(2.8 \%)$.

Correlational analyses indicated a significant links between type of participant's education and the perception of premarital sexual behavior among adolescents. Participants from SMK reported to have higher risk of premarital sexuality than adolescents from SMA. The experience of dating is positively related to the increase in the perceptions of premarital sex among adolescents in this study. Correlational analyses also found that fathering and the perception of premarital sex in which participants who perceived to experience negative fathering reported high risk in the perceptions of premarital sexual behaviour. In addition, the use of social media is significantly positively related to perceptions of premarital sex. Participants who reported to use social media for positive aspects, such as socialization and information perceived low level of premarital sex (Table 2). 
A multiple linear regression test using the classical assumption test found adjusted $\mathrm{R}$ square of 0.146 of the model. The regression model indicated that 14.6 percent of adolescent premarital sex variance in this study was explained by changes in the regression model variables. The remaining 85.4 percent of premarital sex was influenced by other variables that were not tested in this study (Table 3).

Regression analyses found that four independent variables had significant effects on perception of premarital sex among adolescents. Participant's education, dating experience, perceptions of fathering, and use of social media revealed as unique factors for the perception of premarital sex among adolescents. Participant's education had a negative effect $(B=-0.164)$ on the increase in perception of premarital sex by 0.164 points. Experience of dating has a positive effect $(B=0.148)$ on the increase in perceptions of premarital sex by 0.148 points. Fathering has a negative effect $(B=-0.295)$ on the increase in perceptions of premarital sex by 0.295 points. The effect of social media use is positive (0.223) on the increase in perception of premarital sexual activity by 0.223 points. Meanwhile, the peer attachment test results on the regression model did not show a significant effect on perception of premarital sex, although it was positive. 
The relationship test results between the characteristics of adolescents and fathers with peer attachment, fathers' care, use of social media, and premarital sex showed a relationship between variables.

Table 2. Result of Correlation Among Adolescent Characteristics, Father Characteristics, Peer Attachment, Fathering, Social Media Use with Perception of Premarital Sexual

\begin{tabular}{|c|c|c|c|c|c|c|c|c|c|c|c|c|}
\hline Variable & 1 & 2 & 3 & 4 & 5 & 6 & 7 & 8 & 9 & 10 & 11 & 12 \\
\hline 1. Age of adolescents & 1 & .021 & -.020 & .036 & $.178 * *$ & $.113 *$ & -.077 & -.006 & .059 & -.036 & .033 & .020 \\
\hline 2. Gender $(0=$ Male $; 1=$ Female $)$ & & 1 & .045 & .033 & -.109 & -.064 & -.011 & -.011 & .019 & -.068 & $.114^{*}$ & -.036 \\
\hline $\begin{array}{l}\text { 3. Type of Education }(0=\mathrm{SMK} \text {; } \\
\text { 1=SMA) }\end{array}$ & & & 1 & $-.258 * *$ & $-.172 * *$ & $.140 *$ & $.292 * *$ & $.261 * *$ & .108 & .062 & .002 & $-.195 * *$ \\
\hline 4. Origin $(0=$ non Java; $1=$ Java $)$ & & & & 1 & -.034 & -.086 & -.044 & .054 & -.076 & -.097 & -.077 & .026 \\
\hline $\begin{array}{l}\text { 5. Dating Experience }(0=\text { have } \\
\text { never; } 1=\text { have ever })\end{array}$ & & & & & 1 & .015 & -.106 & $-.197 * *$ & .039 & -.074 & .047 & $.195 * *$ \\
\hline 6. Age of Fathers & & & & & & 1 & .002 & $-.150 * *$ & .080 & $-.138^{*}$ & $-.110^{*}$ & -.039 \\
\hline $\begin{array}{l}\text { 7. Education }(0=<\text { Senior High } \\
\text { School; } 1=\text { Bachelor degree })\end{array}$ & & & & & & & 1 & $.435 * *$ & .098 & .041 & -.044 & -.106 \\
\hline $\begin{array}{l}\text { 8. Income }(0=<3 \text { juta; } 1=>3 \\
\text { juta })\end{array}$ & & & & & & & & 1 & .068 & $.185^{* *}$ & -.061 & -.084 \\
\hline 9. Peer Attachment & & & & & & & & & 1 & $.262 * *$ & .107 & -.090 \\
\hline 10. Fathering & & & & & & & & & & 1 & $.134 *$ & $-.269 * *$ \\
\hline 11. Social Media Use & & & & & & & & & & & 1 & $.150 * *$ \\
\hline 12. Premarital Sex & & & & & & & & & & & & 1 \\
\hline
\end{tabular}


Table 3. Regression Coefficient of Adolescent and Father Characteristics, Peer Attachment, and Social Media Use on Perception of Premarital Sex among Adolescents

\begin{tabular}{|c|c|c|c|}
\hline \multirow[b]{2}{*}{ Variable } & \multicolumn{3}{|c|}{ Premarital Sexual } \\
\hline & B & $\beta$ & Sig. \\
\hline (Constanta) & 2.240 & & 0.000 \\
\hline \multicolumn{4}{|l|}{ Adolescents characterics } \\
\hline Age (year) & -.011 & -.019 & 728 \\
\hline Gender $(0=$ Male; $1=$ Female $)$ & -.062 & -.052 & .327 \\
\hline Type of Edication ( $0=$ SMK; $1=$ SMA) & -.164 & -.155 & $.009 *$ \\
\hline Origin $(0=$ others of Java; $1=$ Java $)$ & -.044 & -.035 & .528 \\
\hline Dating Experience ( $0=$ have never; $1=$ have ever) & 148 & 146 & $.008 *$ \\
\hline \multicolumn{4}{|l|}{ Fathers characteristics } \\
\hline Age (year) & -.003 & -.041 & .455 \\
\hline $\begin{array}{l}\text { Education }(0=<\text { Senior High School; } 1=\text { Bachelor } \\
\text { Degree })\end{array}$ & -.057 & -.057 & 341 \\
\hline Income $(0=<3$ juta $; 1=>3$ juta $)$ & .071 & .069 & .262 \\
\hline Peer Attachment & .003 & . 004 & 947 \\
\hline Fathering & -.295 & -.315 & $.000 * *$ \\
\hline Social Media Use & 223 & 191 & .000 *** \\
\hline $\mathrm{R}^{2}$ & & 0.175 & \\
\hline Adjusted $\mathrm{R}^{2}$ & & 0.146 & \\
\hline $\mathrm{F}$ & & 5.960 & \\
\hline Sig & & 0.000 & \\
\hline
\end{tabular}

\section{Discussions}

The research found that participants from SMA reported having a lower perception of premarital sexual behavior than participants from SMK. This finding is in line with Maesaroh et al. (2019), who indicated that adolescents from SMA have a higher external protective factor in the family compared to adolescents from SMK. In addition, the experience of dating has a positive relationship with the perceptions of premarital sexual behavior. Adolescents with dating relationships in this study reported to have higher perceptions of sexual behavior than adolescents with no dating experience. The findings are in line with the research conducted by Nurhidayah et al. (2012), which found a significant relationship between adolescents who have boyfriends with sexual behavior, meaning that adolescents who have had a boyfriend will have a higher perception of premarital sexual behavior.

Perceptions of positive fathering are associated with a low score of premarital sexual behaviors. This is in line with Nurhidayah et al. (2012); Zuhairah and Tatar (2017) study in which fathe's involvement in parenting can reduce juvenile delinquency behavior, including premarital sexual behaviour. In addition, the involvement of fathers in parenting has a significant positive relationship with adolescent self-concept. Good adolescent self-concept reduces juvenile delinquency's contributing factors (Faradila \& Kristiana, 2018). Handayani and Kustanti (2018) also found that the more positive the perception of fathers' involvement in parenting, the lower the intention of premarital sexual behavior and vice versa. 
Also, the use of social media can significantly increase score of the preceptions of premarital sexual behavior. This is in line with the research of Fadillah and Widyastuti (2018); Naja, Agusyahbana, and Mawarni (2017); Solikah et al. (2015) that there is a significant relationship between social media and sexual behavior. Teens who have a good knowledge of social media even fall into the world of free sex (Solikah et al., 2015).

Although extensive research found there was significant effect of attachments on the attitude of premarital sexual behavior (Irmawati, 2013; Suparmi \& Isfandri, 2016) due to the influences of the social life and self-development in adolescents (Bronberg \& O'Donohue, 2013; Kamilda, 2019), the finding of the research did not support the previous research findings. Future research may investigate this relationship.

Regression analyses found that type of education has a significant negative effect on premarital sexual behavior perceptions. Participants from SMK reported to have higher perceptions of premarital sexual behaviours than those from SMA. Maesaroh et al. (2019) show significant differences in adolescents who attend high school, which are higher in the aspects of self-acceptance and external factors in the family dimension than adolescents in SMK. This aspect is related to how the youth relationship with the family. This is related to the factors that influence adolescent sexual behavior originating from external factors such as friends, environment, and parents (Susanti \& Setyowati, 2013). In addition, the findings of Irmawaty (2013) strengthen the previous findings by indicating that family roles have impacts on lower score of premarital sexual behaviours among teenagers and vice versa. family as the main influence that shapes children's behavior (Hastuti, 2015). Therefore, when SMK adolescents feel uncomfortable with their family relationships, perhaps it would increase the perceptions of sexual behavior among them.

Adolescence is a period of physical and psychological development, psychological changes as marked by adolescents' attraction to the opposite sex in the form of dating (Ratnawati \& Astati, 2019). In this study, it was found that the experience of dating has a significant positive effect on sexual behavior. This indicates that adolescents with dating experiences reported to have high perceptions of premarital sexual behavior. This result is in line with the research by Oktriyanto and Alfiasari (2019) that teenagers who are dating have a higher chance of having premarital sex than adolescents who are not dating. According to BKKBN (2010), there are three factors that have three times greater influence to sexual relations among adolescents, including adolescents with dating relationships, friends who agree and friends who encourage premarital relations. It is still difficult during adolescence to distinguish between expressions of affection and sexual urges, which results in adolescents easily fall into sexual activity (Rusmiati \& Hastono, 2015).

The involvement of fathering has a significant negative effect on sexual behavior. This indicated that fathers' positive involvement in parenting could effectively reduce the risk of sexual behavior among adolescents. According to Zuhairah and Tatar (2017), fathers' willingness to be involved in caring for and supervising children can reduce the chances of developing behavior problems in adolescents. Utami et al. (2016) found that the father's authoritative parenting style influences the better adolescents' character building. Previous research showed that 
the influence of the involvement of the father's positive influence on the intention of premarital sexual behavior was getting lower (Handayani \& Kustanti, 2018).

Fathering affects various aspects of children's development such as social adjustment (Basuki \& Indrawati, 2017), relationships with partners, morals and sexual roles (Lamb, 2000) and many other things. This study found that the positive fathering was related to peer attachment, social media use, and sexual behavior. When fathers are involved in positive parenting, it increases youth in positive aspects and vice versa. Father-adolescent insecure attachment pattern was found to increase in juvenile delinquency (Fitriani \& Hastuti, 2016).

The use of social media has a significant positive effect on sexual behavior. This indicates that adolescents who use social media and frequently use it in various ways can increase sexual behavior. This is in line with Chia (2006) that media use affects teenage sexuality. Social media has a major influence on youth attitudes to life and has both positive and negative impacts. The most dominant factor to influence the perceptions of sexual behaviour was the exposure to information media (Suharsa, 2006). The research results by Fadillah and Widyastuti (2018) found that adolescents who have a high dependence on social media have high-risk sexual behavior as much as 57.3 percent, which shows that teens who are very active in social media have a high risk of sexual behavior. Social media seeks information and communicates in various ways and produces short-term effects and changes in knowledge (Wahyuningtias \& Wibisono, 2018). However, adolescents who have a good knowledge of social media fall into free sex (Solikah et al., 2015).

In this study, there was no effect of adolescent age, gender, and regional origin on sexual behavior. This is in line with Rusmiati and Hastono (2015) research that there is no interaction between age and sexual behavior of adolescents in dating. According to Widyastuti (2009), it was found that friends' sexuality had the greatest influence on friends' attitudes regarding premarital sex and then gender. In this study, the highest number of sexes was female 76.3 percent and the rest were men, this is possible to cause no relationship and the influence of gender on sexual behavior because according to Oktariyatni and Alfiasari (2016); Widyastuti (2009), boys are more permissive about premarital sex than girls. According to Putri (2015) found that age is not related and affects adolescent sexual behavior because when interviewed more deeply, adolescents have started dating since elementary school. Factors that influence adolescent sexual behavior are external factors (parents, friends, media) and internal factors (adolescent individuals) (Susanti \& Setyowati, 2013). Internal factors in adolescents are more directed at how self-esteem, selfconcept, self-esteem and attitudes are in adolescents regardless of age, gender or area of origin.

Besides many aspects found regarding the perceptions of premarital sexual behavior among adolenscents in this study, there are numbers of limitations that have to be considered for future research. The limitation is the research using premarital sex instruments that only measure adolescent attitudes towards premarital sexual behavior perceptions. The use of parenting instruments consists of nine detailed dimensions and several question items that are not commonly found in Indonesian culture and the research conducted has only reached 24 provinces and a total of 320 adolescents respondents still do not represent the adolescent population in Indonesia. 


\section{Conclusion and Recommendations}

\section{Conclusions}

The present study found that majority of participants reported to have low attachment (71.6\%), medium attachment (22.8\%), and high attachment (5.6\%). The majority of adolescents perceived to experience moderate fathering with $85.3 \%$. Only $14.4 \%$ participants perceived to have positive fathering and only $0.3 \%$ adolescents in this study reported to have negative fathering. Most of the adolescents were in the low category of social media use $(73.4 \%)$, medium category $(17.8 \%)$, and high category (8.8\%). Regarding the perceptions of pre-marital sexual behavior, majority participants reported to have good category $(73.1 \%)$, moderate category $(24.1 \%)$, and not good $(2.8 \%)$.

In this study, participants from SMA reported to have lower perception of premarital sexual behavior than participants from SMK. Perceptions of positive fathering are associated with a low score of premarital sexual behaviors. The use of social media can significantly increase score of the preceptions of premarital sexual behavior. In addition, if the adolescents have unsafe attachments with their peers, it increases sexual behavior.

This study found that type of education, dating experiences, negative fathering, and social media use revealed to be the significant factors to the perceptions of premarital sexual behaviors among adolescents. There was no effect of adolescent age, gender, and regional origin on premarital sexual behavior perceptions. There is a significant positive relationship between the experience of dating and social media use with perception of premarital sex, and there is a significant negative relationship between the types of adolescent education and fathering with perception of premarital sex among adolescents. There is a significant negative effect of the type of education and fathering on perception of premarital sex. The experience of dating and the social media use has a significant positive effect on perception of premarital sex. There is no significant effect of peer attachment to perception of premarital sex among adolescents.

\section{Recommendation}

There are several aspects that can be recommended through this study. First, the future study shall observe more regarding the premarital sexual behaviours using adolescent's experiences. Therefore, more comprehensive data will be collected to support the study's findings. Second, the future research is suggested to employ parenting instruments developed in Indonesian context to gather more informations to strengthen findings of the study. Lastly, future study are encouraged to reach more diverse participants to picture more nuance Indonesian representations.

\section{References}

Armsden, G. C., \& Greenberg, M. T. (1987). The inventory of parent and peer attachment: Individual differences and their relationship to psychological wellbeing in adolescence. Journal of youth and adolescence, 16(5), 427-454. Doi: https://doi.org/10.1007/BF02202939. 
Azinar, M. (2013). Perilaku seksual pranikah berisiko terhadap kehamilan tidak diinginkan. Jurnal Kesehatan Masyarakat (KEMAS), 8(2), 153-160. Doi: https://doi.org/10.15294/kemas.v8i2.2639.

Badan Pusat Statistik. (2017). Survei Demografi dan Kesehatan Indonesia 2017: Buku Remaja. Retrieved from: https://e-koren.bkkbn.go.id/wpcontent/uploads/2018/10/Laporan-SDKI-2017-Remaja.pdf

Basuki, N. W., \& Indrawati, E. S. (2017). Hubungan antara persepsi terhadap keterlibatan ayah dalam pengasuhan dan penyesuaian sosial pada mahasiswa Fakultas Teknik angkatan 2015 Universitas Diponegoro. Empati, 6(1), 312$316 . \quad$ Retrieved from: https://ejournal3.undip.ac.id/index.php/empati/article/view/15127.

Brislin, R. W. (1970). Back-translation for cross-cultural research. Journal of Cross-Cultural Psychology, 1(3), 185-216. Doi:10.1177/135910457000100301.

Bromberg, D. S., \& O'Donohue, W. T. (2013). Handbook of child and adolescent sexuality: Developmental and forensic psychology. Academic Press. Doi: http://dx.doi.org/10.1016/B978-0-12-387759-8.00001-5.

Chia, S. C. (2006). How peers mediate media influence on adolescents' sexual attitudes and sexual behavior. Journal of communication, 56(3), 585-606. Doi:10.1111/j.1460-2466.2006.00302.

de Paul Kanwetuu, V., Mokulogo, R. K., \& Azumah, F. D. (2018). Understanding adolescents' sexual behaviour in Ghana: information sources and their effects. Sexuality \& Culture, 22(3), 942-961.

Dick, G. L. (2004). The fatherhood scale. Research on social work practice, 14(2), 80-92. Doi: 10.1177/1049731503257863.

Fadillah, R., \& Widyatuti, W. (2018). Perilaku pengguna media sosial dengan perilaku seksual pranikah ada remaja SMA. Jurnal Ners Widya Husada Semarang, 5(3), 87-94. Doi: https://doi.org/10.33666/jners.v5i3.337.

Faradila Marsuq, A., \& Kristiana, I. F. (2018). Hubungan antara persepsi terhadap keterlibatan ayah dalam pengasuhan dengan konsep diri pada siswa kelas $\mathrm{X}$ SMK Negeri 4 Kendari. Empati, 6(4), 247-253. Retrieved from: https://ejournal3.undip.ac.id/index.php/empati/article/view/20063.

Fitriani, W., \& Hastuti, D. (2016). Pengaruh kelekatan remaja dengan ibu, ayah, dan teman sebaya terhadap kenakalan remaja di Lembaga Pembinaan Khusus Anak (LPKA) Kelas II Bandung. Jurnal Ilmu Keluarga \& Konsumen, 9(3), 206-217. Doi: https://doi.org/10.24156/jikk.2016.9.3.206.

Gupta, S., \& Bashir, L. (2018). Social networking usage questionnaire: Development and validation in an Indian higher education context. Turkish Online Journal of Distance Education, 19(4), 214-227. Retrieved from: https://eric.ed.gov/?id=EJ1192794.

Handayani, W., \& Kustanti, E. R. (2018). Hubungan antara persepsi terhadap keterlibatan ayah dalam pengasuhan dengan intensi perilaku seksual pranikah pada remaja. Empati, 7(1), 188-194. Retrieved from: https://ejournal3.undip.ac.id/index.php/empati/article/view/20185.

Hastuti, D. (2015). Pengasuhan teori, prinsip, dan aplikasinya di Indonesia. Bogor: PT Penerbit IPB Press. 
Inguglia, C., Costa, S., Ingoglia, S., Cuzzocrea, F., \& Liga, F. (2020). The role of parental control and coping strategies on adolescents' problem behaviors. Current Psychology, 1-14. Doi: 10.1007/s12144-020-00648-w.

Irmawaty, L. (2013). Perilaku seksual pranikah pada mahasiswa. KEMAS: Jurnal Kesehatan Masyarakat, 9(1), 44-52. Doi: https://doi.org/10.15294/kemas.v9i1.2829.

IDN TIMES. (2018, July). Kemenkes: 98.3 persen pelajar terpapar pornografi. Retrieved from: https://www.idntimes.com/news/indonesia/indianamalia/kemenkes-983persen-pelajar-terpapar-pornografi.

Kamilda, M. R. (2019). Perbedaan Perilaku Seks Bebas Remaja Ditinjau Dari Tipe Pola Asuh Orang Tua Di Smk Batik 1 Surakarta. IMJ (Indonesian Midwifery Journal), 2(1), 10-18. Doi: http://dx.doi.org/10.31000/imj.v2i1.791.g1344.

Kurniawati, A. (2017). Faktor-faktor yang memengaruhi perilaku seks remaja SMA dan SMK di kecamatan ciawi kabupaten tasikmalaya tahun 2016. Jurnal BIMTAS: Jurnal Kebidanan Umtas, 1(2), 24-29. Retrieved from: https://umtas.ac.id/journal/index.php/bimtas/article/view/489.

Kusumaryani, M., \& Antarwati, E. (2017). Brief Notes: prioritaskan kesehatan reproduksi remaja untuk menikmati bonus demografi. Lembaga Demografi FEB UI, 1-6. Retrieved from: https://ldfebui.org/wpcontent/uploads/2017/08/BN-06-2017.pdf.

Lamb, M. E. (2000). The history of research on father involvement. Marriage \& Family Review, 29(2-3), 23-42. Doi:10.1300/j002v29n02_03.

Maesaroh, S., Sunarti, E., \& Muflikhati, I. (2019). Ancaman, Faktor Protektif, dan Resiliensi Remaja di Kota Bogor. Jurnal Ilmu Keluarga \& Konsumen, 12(1), 63-74. Doi: http://dx.doi.org/10.24156/jikk.2019.12.1.63.

Maimunah, S. (2015). Pengaruh faktor keluarga terhadap perilaku seksual remaja. In Seminar psikologi dan Kemanusiaan (pp. 359-62). Retrieved from: http://mpsi.umm.ac.id/files/file/359-362\%20Siti\%20Maimunah.pdf

McMillan, C., Felmlee, D., \& Osgood, D. W. (2018). Peer influence, friend selection, and gender: How network processes shape adolescent smoking, drinking, and delinquency. Social networks, 55, 86-96.

Mpondo, F., Ruiter, R. A., Schaafsma, D., Van Den Borne, B., \& Reddy, P. S. (2018). Understanding the role played by parents, culture and the school curriculum in socializing young women on sexual health issues in rural South African communities. SAHARA-J: Journal of Social Aspects of HIV/AIDS, 15(1), 42-49.

Naja, Z. S., Agusyahbana, F., \& Mawarni, A. (2017). Hubungan pengetahuan, sikap mengenai seksualitas dan paparan media sosial dengan perilaku seksual pranikah pada remaja di beberapa SMA kota Semarang triwulan II tahun 2017. Jurnal Kesehatan Masyarakat (e-Journal), 5(4), 282-293. Retrieved from:

https://ejournal3.undip.ac.id/index.php/jkm/article/download/18364/17444.

Najib, N. (2018). Pola asuh dan peer group terhadap konsep diri remaja tentang perilaku seksual. HIGEIA (Journal of Public Health Research and Development), 2(4),

645-653. Doi: https://doi.org/10.15294/higeia.v2i4.26931. 
Nasution, I. N., \& Septiani, D. (2017). Perkembangan regulasi emosi anak dilihat dari peran keterlibatan ayah dalam pengasuhan. Psychopolytan: Jurnal Psikologi, $\quad 1(1), \quad$ 23-30. $\quad$ Retrieved from: http://jurnal.univrab.ac.id/index.php/psi/article/view/330.

Nurhidayah, S., Prestiana, N. D. I., \& Bayani, I. (2012). Pengasuhan, peer group, self efficacy dan perilaku seks pada remaja perilaku seks pada remaja di kota bekasi. SOUL: Jurnal Pemikiran dan Penelitian Psikologi, 5(2), 67-79. Retrieved from: http://jurnal.unismabekasi.ac.id/index.php/soul/article/view/630.

Oktriyanto, O., \& Alfiasari, A. (2019). Dating and premarital sexual inisiation on adolescence in Indonesia. KEMAS: Jurnal Kesehatan Masyarakat, 15(1), 153160. Doi: https://doi.org/10.15294/kemas.v15i1.17270.

Putri, B. D. (2015). Peran faktor keluarga dan karakteristik remaja terhadap perilaku seksual pranikah. Biometrika dan Kependudukan, 3(1), 8-19. Retrieved from: http://www.journal.unair.ac.id/download-fullpapers.

Putri, W. S. R., Nurwati, N., \& Budiarti, M. (2016). Pengaruh media sosial terhadap perilaku remaja. Prosiding Penelitian dan Pengabdian kepada Masyarakat, 3(1), 47-51. Doi: https://doi.org/10.24198/jppm.v3i1.13625.

Rahardjo, W., Citra, A. F., Saputra, M., Damariyanti, M., Ayuningsih, A. M., \& Siahay, M. M. (2017). Perilaku seks pranikah pada mahasiswa: Menilik peran harga diri, komitmen hubungan, dan sikap terhadap perilaku seks pranikah. Jurnal Psikologi, 44(2), 139-152. Doi: 10.22146/jpsi.23659.

Ratnawati, D., \& Astari, I. D. (2019). Hubungan Tingkat Stres Dengan Perilaku Berpacaran Pada Remaja Di SMA X Cawang Jakarta Timur. Jurnal Profesi Medika: Jurnal Kedokteran dan Kesehatan, 13(1), 15-21. Doi: http://dx.doi.org/10.33533/jpm.v13i1.908.

Reiss, I. L. (1964). The scaling of premarital sexual permissiveness. Journal of Marriage and the Family, 26(2), 188-198. Doi:10.2307/349726.

Rimawati, E. (2010). Fenomena perilaku seksual "ayam kampus" di kota semarang. Jurnal Promosi Kesehatan Indonesia, 5(1), 36-45. Doi: 10.14710/jpki.5.1.36-45.

Rochaningsih, N. S. (2014). Dampak pergeseran peran dan fungsi keluarga pada perilaku menyimpang remaja. Jurnal Pembangunan Pendidikan: Fondasi dan Aplikasi, 2(1), 59-71. Doi 10.21831/jppfa.v2i1.2618.

Rosdarni, R., Dasuki, D., \& Waluyo, S. D. (2015). pengaruh faktor personal berpengaruh terhadap perilaku seksual pranikah pada remaja di Kota Kendari Provinsi Sulawesi Tenggara. Kesmas: National Public Health Journal, 9(3). 214-221. Doi: http://dx.doi.org/10.21109/kesmas.v9i3.567.g450.

Rostiawan, F., Yusuf, S., \& Dahlan, T. H. (2020, February). Positive Parenting Program to Increase Parental Monitoring Toward Youth Sexual Behavior. In International Conference on Educational Psychology and Pedagogy-" Diversity in Education"(ICEPP 2019) (pp. 73-75). Atlantis Press.

Rusmiati, D., \& Hastono, S. P. (2015). Sikap remaja terhadap keperawanan dan perilaku seksual dalam berpacaran. Kesmas: National Public Health Journal, 10(1), 29-36. Doi:http://dx.doi.org/10.21109/kesmas.v10i1.815.

Santrock, J. W. (2019). Life-Span Development (seventeenth edition). Retrieved from: https://b-ok.asia/book/5010268/b15f2e. 
Setiawan, R., \& Nurhidayah, S. (2008). Pengaruh pacaran terhadap perilaku seks pranikah. SOUL: Jurnal Pemikiran dan Penelitian Psikologi, 1(2), 59-72. Retrieved from: https://pdfs.semanticscholar.org/aaa6/3a971c8607c5fef4cf57c94c09b908be79 05.pdf.

Solikah, I. A., Herlina, N., \& Masnina, R. (2015). Hubungan antara peran media sosial dan peran orang tua dengan perilaku seks pranikah pada remaja kelas xii di smkn 4 samarinda (Skripsi, Universitas Muhammadiyah Kalimantan Timur). Retrieved from: https://dspace.umkt.ac.id/handle/463.2017/1324.

Suharsa, H. (2006). Perilaku seksual remaja pada siswa sekolah menengah atas serta faktor-faktor yang memengaruhi di Kabupaten Pandeglang Tahun 2006 (Tesis, Universitas Indonesia, Indonesia). Retrieved from: http://juliwi.com/published/E0302/Juliwi0302_32-43.pdf.

Suparmi, S., \& Isfandari, S. (2016). Peran teman sebaya terhadap perilaku seksual pranikah pada remaja laki-laki dan perempuan di Indonesia. Buletin Penelitian Kesehatan, 44(2), 139-146. Retrieved from: https://www.neliti.com/publications/67963/peran-teman-sebaya-terhadapperilaku-seksual-pranikah-pada-remaja-laki-laki-dan\#cite.

Susanti, E., \& Setyowati, R. N. (2013). Persepsi siswa kelas xi smk negeri 4 surabaya terhadap perilaku seks bebas di kalangan pelajar surabaya. Kajian Moral dan Kewarganegaraan, 3(1), 616-630. Retrieved from: https://jurnalmahasiswa.unesa.ac.id/index.php/jurnal-pendidikankewarganegaraa/article/download/4255/2060.

Suwarni, L. (2009). Monitoring parental dan perilaku teman sebaya terhadap perilaku seksual remaja SMA di kota Pontianak. Jurnal Promosi Kesehatan Indonesia, 4(2), 127-133. Doi: https://doi.org/10.14710/jpki.4.2.127-133.

Suwarni, L., Ismail, D., Prabandari, Y. S., \& Adiyanti, M. G. (2015). Perceived parental monitoring on adolescence premarital sexual behavior in Pontianak City, Indonesia. Int J Public Health Sci, 4(4), 211-219. Retrieved from: https://www.researchgate.net/profile/Linda_Suwarni2/publication/337018533 _Perceived_Parental_Monitoring_on_Adolescence_Premarital_Sexual_Beha vior_in_Pontianak_City_Indonesia/links/5e03ce1592851c83649b4324/Percei ved-Parental-Monitoring-on-Adolescence-Premarital-Sexual-Behavior-inPontianak-City-Indonesia.pdf.

Tomić, I., Burić, J., \& Štulhofer, A. (2018). Associations between Croatian adolescents' use of sexually explicit material and sexual behavior: does parental monitoring play a role?. Archives of Sexual Behavior, 47(6), 18811893.

Utami, A. N., Hernawati, N., \& Alfiasari, A. (2016). Pengasuhan orang tua yang seimbang sebagai kunci penting pembentukan karakter remaja. Jurnal Pendidikan Karakter, (1), 1-16. Doi: https://doi.org/10.21831/jpk.v0i1.10727

Widyastuti, E. S. A. (2009). Personal dan sosial yang memengaruhi sikap remaja terhadap hubungan seks pranikah. Jurnal Promosi Kesehatan Indonesia, 4(2), 75-85. Doi: https://doi.org/10.14710/jpki.4.2.75-85.

Zakiyah, R., Prabandari, Y. S., \& Triratnawati, A. (2016). Tabu, hambatan budaya pendidikan seksualitas dini pada anak di Kota Dumai. Berita Kedokteran Masyarakat, 32(9), 323-330. Doi: https://doi.org/10.22146/bkm.10557. 
Zuhairah, Z., \& Tatar, F. M. (2017). Hubungan antara keterlibatan ayah dalam pengasuhan dengan kenakalan remaja di kota Banda Aceh. Jurnal Pencerahan, 11(1), 46-52. Doi: 10.13170/jp.11.1.8315. 